\title{
Teachers in COVID-19 period: Psychological effects, practices and career needs
}

\author{
Hasan Eşici iD \\ Hasan Kalyoncu University Education Faculty, Gaziantep, Turkey, hsnesici@gmail.com \\ Ahmet Ayaz ${ }^{(D)}$ \\ Hasan Kalyoncu University Education Faculty, Gaziantep, Turkey, ahmet.ayaz@hku.edu.tr \\ Defne Yetim ${ }^{(D)}$ \\ Empathy Special Education and Rehabilitation Center, Gaziantep, Turkey, defneytm@gmail.com \\ Sümeyye Çağlar Yastı \\ Ministry of National Education, Gaziantep, Turkey, sumeyye.cglr@ hotmail.com \\ Nurşen Bedir \\ Ministry of National Education, Gaziantep, Turkey, pdr.nursen06@gmail.com
}

Check for updates

\begin{abstract}
The purpose of the current study was to examine teachers' career needs and psychosocial experience during the COVID-19 pandemic within the phenomenological pattern of qualitative research methods. The data collection process included individual interviews and an online survey form. As a result of the research, four main themes were obtained. The first of these themes concerned the effects of the COVID19 process on teachers. These effects were divided into both positive and negative effects. The second main theme focused on the needs of teachers. In this process, teachers felt the need for psychological support, in-service training and support for infrastructure. The third main theme was the professional life of teachers and school counselors. In this process, teachers and school counselors continued their education, teaching and support processes by adapting them to the online environment. The last main theme was the problems experienced in this process and the proposed solutions. Participants highlighted problems in this period, particularly the access of students to education. Recommendations were made as part of the research results to strengthen the educational training activities offered by teachers in the COVID-19 period.
\end{abstract}

Keywords: Careerneeds, COVID-19, Teachers

\section{COVİD-19 döneminde öğretmenler: Psikolojik etkiler, uygulamalar ve kariyer ihtiyaçları}

ÖZ Bu çalışmanın amacı kapsamında, COVID-19 pandemi sürecinde öğretmenlerin kariyer ihtiyaçları ve psikososyal deneyimleri nitel araştırma yöntemlerinden olgubilim deseni temel alınarak incelenmiştir. Veri toplama süreci bireysel görüşmeler ve çevrimiçi anket formu aracılığıyla gerçekleştirilmiştir. Araştırma sonucunda dört ana tema elde edilmiştir. Bu temalardan ilki COVID-19 sürecinin öğretmenler üzerindeki etkileridir. Bu etkiler pozitif ve negatif etkiler olarak ikiye ayrılmıştır. İkinci ana tema öğretmenlerin ihtiyaçlarına yöneliktir. Bu süreçte öğretmenler psikolojik destek, hizmetiçi eğitim ve altyap1 konusunda destek ihtiyacı hissetmektedir. Üçüncü ana tema ise öğretmen ve okul psikolojik danışmanların mesleki yaşantılarını oluşturmaktadır. Bu süreçte öğretmen ve okul psikolojik danışmanları eğitim öğretim ve destek süreçlerini çevrimiçi ortama uyarlayarak devam ettirmişlerdir. Bununla birlikte öğretmen ve psikolojik danışmanlar öğrenci ve velilere eğitim öğretim sürecinin dışında da destek vererek, iyi oluş düzeylerine katkı sağlamaktadırlar. Son ana tema ise COVID-19 sürecinden alınan tedbirlerle ilgili yaşanan problemler ve çözüm önerilerine yöneliktir. Katılımcılar bu süreçte özellikle öğrencilerin eğitime erişimlerine yönelik problemleri vurgulamıştır. Araştırma sonuçları kapsamında COVID-19 sürecinde öğretmenler tarafından sunulan eğitim öğretim faaliyetlerinin güçlendirilmesine yönelik önerilerde bulunulmuştur.

Anahtar

Sözcükler: COVID-19, Kariyer ihtiyaçlarl, Öğretmenler

\footnotetext{
Citation: $\quad$ Psychological effects, practices and career needs. Turkish Journal of Education, 10(2), 157-177.
$\quad$ Psych https://doi.org/10.19128/turje.855185
} 


\section{INTRODUCTION}

In different parts of the world, list of pandemics has been updated with new types of viruses that can affect people en masse every year (World Health Organization [WHO], 2020a). The outbreak of COVID-19, which started in December 2019, has been declared as a pandemic by the WHO. Unlike other pandemics seen in the history of the organization, the United Nations defined COVID-19 as a humanitarian, economic and social crisis that attacks the foundations of societies beyond the health crisis (United Nations [UN], 2020). The WHO has reviewed the risk assessment for COVID-19 on a regular basis, while countries around the world have worked to prevent the spread and recovery of patients (WHO, 2020b; European Centre for Disease Prevention and Control [ECDC], 2020). COVID-19 has deeply affected the economic, social and educational systems of countries along with the health systems (Şen \& Bat1; 2020). Although the measures taken in many regions have reduced the negative effects that occur in pandemic societies to a relative degree, they have not been able to completely stop the deterioration (World Economic Forum, 2020). The schools in Turkey were immediately closed on 16 March 2020 and switched to distance education through Education Information Network (EBA) and EBA TV on 23 March 2020 (The Ministry of Education [MoNE], 2020a). Approximately twenty million students and one million teachers have tried to adapt to the distance education process in Turkey. During this period, what teachers needed became important. The aim of this study was to determine the psychological effects of pandemic on teachers, the practices they perform in their professional work and their career needs during the COVID-19 period in Turkey.

Teachers, along with all professional areas, are among those affected by the COVID-19 period. Transition to the online education process, which is one of the biggest reflections of COVID-19 on education in many countries, has been a situation where teachers have to adapt quickly and compulsively (Allen et al., Rowan \& Singh, 2020; Carver \& Shanks, 2021; Wang et al., 2021). Studies indicated that teachers were intensely anxious during the transition to online education (Košir et al., 2020; Truzoli et al., 2021). This concern was more intense among private school teachers (Allen et al., 2020). With online education, teachers started to communicate with students using online communication programs (Lestiyanawatir, 2020). Although this situation ensured the continuation of the learning environment, it negatively affected the learning process with the decrease of social interaction (Ewing \& Cooper, 2021; Sepulveda-Escobar \& Morrison, 2020). School counselors also tried to reach students with similar methods and supported their well-being. School counselors who actively use technology have adapted more easily to the online education process (Karaman et al., 2021; Supriyanto et al., 2020). One of the most important factors facilitating teachers' adaptation to the online education process has been their information and communication (ITC) skills (König et al., 2020). These skills also have a role in reducing the stress experienced by teachers (Košir et al., 2020).

Teachers reported that they experienced problems related to the increasing workloads (Allen et al., 2020; Giovannella et al., 2020), the low level of work motivation (Purwanto et al., 2020), and time management (Giovannella et al., 2020) during the pandemic. Besides these problems, another issue was the problems of teachers and students accessing the internet, course materials and technological tools, and increasing costs to of technological devices and services (Purwanto et al., 2020). Families were one of the groups that were negatively affected in the process and felt a burden on their shoulders. Hence, this has caused them to be particularly weak in providing educational support to their children. This has made teachers' jobs more difficult (Allen et al., 2020; Ewing \& Cooper, 2021; Lestiyanawatir, 2020; Karaman et al., 2021).

Along with these problems, the process of transition to online education has also had positive effects on teachers. In this process, it has been seen that teachers have developed their digital skills, had the idea of using educational technologies actively in post-pandemic processes (Giovannella et al.,2020), had more flexible working hours and considered this situation having free time (Purwanto et al., 2020). 
In Turkey, teachers were both psychologically affected by this process and were unable to perform their profession in school and classroom settings for the first time (MoNE, 2020b). Courses and practices in which teachers in Turkey can acquire the knowledge and skills they may need during periods of major disasters and crises, especially pandemics such as the COVID-19 period, are very limited in pre-and inprofessional education processes. In other words, courses and practices such as distance education, crisis management and psycho-social rehabilitation in educational faculties have been very limited (The Council of Higher Education [CoHE, 2018). Among the in-service training courses prepared by MoNE, subjects such as distance education, development of technological competencies, civil defense and disaster were addressed very limited (MoNE, 2006). When the in-service training plans of the Directorate General for Teacher Training and Development of the Ministry of Education are reviewed for 2019, it has been seen that training has been carried out on topics such as disaster, information and communication technologies and psychosocial support (MoNE, 2020c). In addition, an in-service training program including digital skills development, project, foreign language training, disaster training has been announced by the MoNE for 500 thousand teachers during COVID-19 period (MoNE, 2020d).

United Nations Educational, Scientific and Cultural Organization (UNESCO, 2020) stated that about 1.3 billion students in 186 countries around the world were unable to receive education due to the closure of schools as a result of COVID-19. During this period, decisions were taken on the online education model, but the repercussions of these decisions on teachers and students were different. Some students and teachers had difficulty accessing tools, such as computers and the Internet, and there was a risk of technology dependence among those who could access it (Fagell, 2020; Heymann, 2020).

In addition, with COVID-19, inequalities between different social segments have increased and a gap in access to education has been formed (Khusid et al., 2020). It has been observed that those who have access to distance education do not receive as much qualified education as to face-to-face education (Lau et al., 2020). According to UN data, the closure of schools and universities has affected the 770 million learners around the world (e.g., students, trainees; Cai et al., 2020). However, schools re-opened and it is one of the primary concerns in the world at the moment. However, it could close again due to a possible increase in COVID-19 after it was opened (Lee, 2020). In the face of the COVID-19 pandemic, teachers and students around the world have had difficulties accessing adequate guidance, training, support and resources in the distance education process. In addition to providing teachers with technological tools, it is important to encourage teachers to use them and to encourage them to improve their practice (Yamamato \& Altun, 2020). In this regard, the COVID-19 period has made two issues important in the context of teachers' career development. These include, first, the psychological empowerment of teachers in crisis situations, and second, the development of professional knowledge and skills of teachers.

First, the psychological survival of teachers in crisis situations among needs for career development in the COVID-19 period was discussed in this study. The psychological strength of teachers is important for the protection of the mental health of society. One million teachers are in contact with 20 million students in Turkey (MoNE, 2020a). Studies have shown that the pandemic period can have negative effects on people psychologically (Gammon, 1999; Güngör et al., 2020; Jonkman et al., 2003; Sarı \& Khorshid, 2008). In addition, large-scale stress factors, such as the pandemic, appear to affect the level of adaptation of individuals (Main et al., 2011). It is normal for teachers to have feelings, thoughts and behaviors similar to any other person during the pandemic period. The way teachers deal with the emotions they experience can be effective in their relationships and communication with their students (Lent et al., 2000). Individuals may prefer to deal actively with stress situations or avoid stress situations (Carver et al., 1989; Tein et al., 2000). It can be stated that the preventive overcoming the stress strategy is more effective in the face of uncontrollable stress factors during the epidemic periods (Gan et al., 2004). In this context, it is important to determine how teachers have been psychologically affected by the epidemic process and to identify the feelings, thoughts and behaviors they have.

Countries, institutions, businesses as well as individuals have been alarmed and mobilized to manage 
this crisis in the post-COVID-19 world. Crisis situations were defined as making decisions that can have an effect on the future and have important consequences (Echterling et al., 2005). Crises refer to both vital events that affect the individual during developmental periods and stressful situations that occur suddenly in life (Demirli-Yıldız et al., 2016). Crises can threaten the objectives of institutions and have profound effects on their relationship with their joint owners (Bundy et al., 2017). Barton (2000) stated that measures taken before situations of crisis arised and preparations were able to minimize the negative effects of the crisis. In order to successfully deal with crisis situations, it is important to approach them continuously and to be environmentally sensitive to a large extent (Maya, 2014). Teachers should be able to know and manage the impact of the crisis on themselves, society, students and parents in order to reduce the impact of the crisis situation with COVID-19 (Truzoli et al., 2021)

The second topic discussed in this study was the development of professional knowledge and skills among the career development needs of teachers in the COVID-19 period. Professions and professional elements were affected by developments and changes in the immediate and external surroundings (Lent et al., 2000). The literature included studies on concepts such as the quality of teachers, empowerment, professional identity and career development (Beijaard et al., 2004; Conley \& Odden, 1995; Hopkins \& Stern, 1996; Huberman, 1989; Lefstein \& Perath, 2014; Öztabay, 2017; Noonan, 2018). Although these concepts were different from each other, what they all have in common was that they contained the characteristics, knowledge, skills and experience that teachers needed to have in order to better fulfill their profession. Teaching profession has processes of professional development as a professional identity (Beijaard et al., 2004; Noonan, 2018). Career development of the teacher was a dynamic feature that developed over time, influenced by the context in which the teacher was located (Huberman, 1989; Noonan, 2018). The career development of teachers depends on increasing their professional knowledge and skills over time (Conley \& Odden, 1995). The teaching profession has been largely shaped by faceto-face and classroom practices up to the COVID-19 period. It is important that teachers adopt different roles within and outside the classroom and receive support so that they can achieve their professional development from the very beginning of their profession (Olsen \& Anderson, 2007). Teachers' preservice and in-service training processes usually focus on applications for school and classroom learning environments (Kaendler et al., 2015). Identically, when the documents relating to teacher qualifications were examined, it was seen that teacher qualifications related to classroom and face-to-face training were at the forefront (MoNE, 2017; Europe Comission, 2013). However, during the COVID-19 period, there was a long break in face-to-face education in all grades, and therefore, educational institutions switched to distance education instead. Although the educational community in the world is no stranger to education studies, it is seen as a fact that educators also do not have training and experience in teaching processes and being facilitators (Varvel, 2007). Distance education was not supported sufficiently in K12-level schools around the world until the COVID-19 period; and involved into the higher education limited (Livingstone, 2012; Varvel, 2007). For this reason, the knowledge and skills of teachers related to distance education in pre-service and in-service training processes are also not sufficiently focused (Carver \& Shanks, 2021). Among the 25 teaching undergraduate programs in Turkey, only the "Open and Distance Learning" course is mandatory in the "Teaching Computer and Instructional Technologies" program, and it is among the elective courses in other programs (CoHE, 2018). Research, however, clearly showed that the needs of teachers include computer skills and the use of technology (Ananiadou \& Rizza, 2010; Enochsson \& Rizza, 2009; Haney \& Lumpe, 1995; Huda et al. 2016; İncik \& Özkan, 2018; Wayman \& Jimerson, 2014). On the one hand, information and communication technologies and distance education, which is needed for career development of teachers, are seen as a difficult situation to follow and learn. In addition to issues such as educational technologies and distance education, COVID-19 obliges teachers to re-question new career development needs, to be considered as an important need in teacher training processes and career development processes for teachers. For this purpose, the study sought to determine the psychological effects of COVID-19 on teachers, their reflections on educational and training processes, and the career needs of teachers during this period. 


\section{METHOD}

The current research was conducted based on the phenomenological pattern of qualitative research methods. The focus of the phenomenological pattern is aimed at a comprehensive study of a particular phenomenon (Yıldırım \& Şimşek, 2016). As part of the research, the professional lives of teachers in the COVID-19 period were studied in-depth through their experiences.

\section{Study Group}

The participants were formed using the maximum variation sampling method. By creating a relatively small sample with maximum variation, the diversity of individuals who may be parties to the problem being studied is reflected to the maximum extent possible (Yıldırım \& Şimşek, 2016). In this study, the participants affected by the problem in the study group were diversified in terms of field, age and city variables, so that different dimensions of the problem were tried to be identified.

Research data were collected in two stages. In the first stage, individual interviews were conducted with the participants. In the second stage, the data was collected through an online questionnaire. In the first stage, there were five males and nine females participants in the study group. The participants working in different cities were included in the interviews. These cities (Manisa, Istanbul, Adana, Gaziantep, Hatay, Trabzon, Antalya, Ağrı, Eskisehir) represents all geographic regions of Turkey. The ages of participants ranged from 24 to 47 years. The seniority of the participants varies from 1 to 20 years. The field of the participants consisted of music, elementary school, geography, mathematics, preschool, literature, special education, philosophy and English teaching, as well as psychological counseling and guidance. In addition, the study group included participants who had bachelor's (8), master's (5) and doctoral (1) degrees. One of the participants work in pre-school, six in primary school, four in middle school, and three in high school.

In the second phase (online survey), total of 76 participants were reached. There were 39 male and 39 female participants in the second phase. The age range of participants ranged from 23 to 53 years. The seniority of the participants ranges from 1 to 33 years. The fields of the participants were mostly the same with the ones in the first phase, with an addition of education of religion and ethics, physics, science, social sciences. In addition, the study group includes participants who have received bachelor's (62), master's (14) and doctoral (1) level education. Seven of the participants work in pre-school, 31 in primary school, 18 in middle school, 21 in high school. The participants in a way that represent geographical regions in Turkey is working in 15 different cities (Izmir, Istanbul, Adana, Gaziantep, Hatay, Turkey, Trabzon, Antalya, Pain, Eskisehir, Izmir, Bursa, Ankara, Turkey, Adiyaman, Ordu, Samsun). In addition, $42 \%$ of the participants work in the city, $30 \%$ in the township and $28 \%$ in the village.

\section{Data Collection Tools}

\section{Individual interview form}

It is aimed to examine the psychological effects of the COVID-19 pandemic on teachers, their reflections on education and training processes and the career needs, which reveal through the individual interview form. The interview form consists of six questions. These questions were aimed at exploring the problems, needs, professional lives and effects of teachers on their careers in the COVID-19 period. During the development of the interview form, the expert opinion was taken from two experts in the field of guidance and counseling and an expert in qualitative research methods. The final version of the interview form has been obtained with expert opinions and the data collection process had begun.

\section{Online survey form}

The online survey form, designed to contribute to data obtained from individual interviews and to ensure 
data diversification, was prepared in accordance with the individual interview form. The online survey form consists of two parts. The demographic information section, which is the first section, gathers information from teachers, such as gender, age, branch and type of school in which they have been assigned. Factors affecting the career development of teachers during the COVID-19 period (problems, needs, experiences and effects) are included in the second section. This section contains six questions, as in the form of the interview.

\section{Data Collection}

The data collection process started with the approval of the ethics committee. Research data have been collected through individual interviews and an online survey form. Data have been collected simultaneously through interviews and online surveys. In this section, first, information is provided on the process of collecting data using the online survey method after the interview.

\section{Individual interviews}

Interviews with participants were conducted by video and voice over the phone, taking into account the health risk of a face-to-face meeting in the COVID-19 period and the possibility that negotiations could not be held with possible interruptions in internet connections. All interviews were conducted by a single researcher. Interview questions were sent to participants before the interview was held, and participants were asked to review the interview questions. In addition, participants were informed about the purpose of the study before the researchers started the interviews. It was then stated to the participants that audio recordings should be taken for use in data analysis, and approval was obtained from the participants that audio recordings could be obtained. The interviews lasted between 35 and 55 minutes. The interviews were conducted using a reflective listening technique, and in this way, the participants felt comfortable and continued to interview.

\section{Online survey form}

The Online survey form has been prepared in line with the individual interview form but is also intended to collect data from a more outnumbering group. The survey form was created using Google Forms and shared with participants. The purpose of the study was explained by the introduction of the form and the participants are informed that they can stop answering to the survey at any time. Participants were given the opportunity to answer six open-ended questions in the survey form without time and character restrictions. The data were downloaded from the database stored in the Google Forms and made available for analysis.

\section{Data Analysis}

The data analysis process was carried out following the four steps proposed by Y1ldırım and Şimşek (2016). These steps include encoding data, finding themes, editing codes and themes, and defining and interpreting findings. Following these steps, the audio recordings obtained from the interviews were first encoded and transferred to the computer environment. In the second stage, the encoded interviews and survey forms were transferred to the MAXQDA 20 program, where data analysis would be performed and a data file ready for analysis was obtained. First, interview forms were coded. After that, the questionnaire forms were coded based on the themes obtained in this coding. In the last stage, the results obtained from the interview and questionnaire forms were reported jointly.

After this stage, a data analysis meeting was held and a transcript of the interview was co-encoded. After co-coding, the three researchers who would conduct the data analysis encoded the remaining interviews independently. After independent coding, the three researchers came together to make a joint coding, and the first draft of the code and the themes was obtained. The draft code and themes were discussed at a meeting attended by all researchers. All the code and themes were discussed at these meetings, and the final code and themes were obtained. 


\section{Credibility and Trustworthiness}

A number of measures have been taken about the cogency and consistency studies in line with the recommendations of Creswell (2012), Yıldırım and Şimşek (2016), and Miles and Huberman (1994). In order to plan and organize the research process and to conduct joint studies, the research team gathered regularly on the online platform between 17.00 and 19.00 on Mondays (Zoom). In this process, all the details of the research are discussed in such a way that the participants can comfortably express their ideas. At the same time, common data encodings and final data encodings were carried out using the same method. At the same time, the code and themes obtained within the scope of the research were sent to the participants who were interviewed, and the confirmation of the participants was obtained from them. Furthermore, based on the rich and detailed description method, both the method section and the findings section of the research were prepared. Information on the research process is detailed and transmitted in the method section, while the results are reported together with the direct statements of the participants. Eventually, information was gathered, and data diversification was provided through an online survey form consisting of both interviews and open-ended research questions.

\section{FINDINGS}

The findings were structured according to five main themes. The effects of the COVID-19 process on teachers, the needs of teachers, the professional lives of teachers and the problems experienced by teachers related to the actions taken and the suggestions for solutions were defined as these themes. Below are sub-themes and participant opinions on these themes. In Figure 1, the corresponding theme and sub-themes are shown. In Figure 1, line width shows the frequencies of the emerged codes.

\section{Effects of the COVID-19 Process on Teachers}

Individuals from different segments of each country were affected by the COVID-19 epidemic process at different levels and ways, affecting the world in a short time. These effects are split into two themes in light of the information obtained from the teachers: negative and positive effects. Anxiety, longing, family conflicts, fear, helplessness, and despair are negative effects that teachers express regarding the process. The anxiety among participants that appears to be the most intense of the negative effects. One participant expressed a state of anxiety as follows: 'There's a certain order, and you're looking for that order. Again, health concerns were added to this disorder. Of course, now that you have a child, you worry twice as much.' Another negative effect is family conflicts. "I think there's going to be a lot of family conflicts, we're really calm people, but we're getting tired of each other." On the other hand, a participation stated the fear experienced in the process as follows: "We're all very hurt in this process, we're very scared, and the uncertainty of this process scares us." Another negative effect that accompanies the period is longing: "Obviously we both missed our order, and we missed our school order. If you say you miss school, we really miss school.", his statements show that longing is aimed at both the old order and the school. The last negative effect experienced in the period is despair: "I have a despair for life against the future."

The positive effects of teachers during the COVID-19 period include professional and personal development, the use of technology and psychological skills. The Professional and personal development is most noticeable among the participants as a recurring effect. A teacher expressed his thoughts on this issue as follows: "I think I'll be different. As I said, I will educate myself in different areas, both personally and professionally. For example, I will definitely participate in all of the one-onone in-service trainings that will be opened in the field of distance education, and I will document my knowledge and experience." A participant stated that the COVID-19 period will have a positive impact on the use of technology: "We have improved the use of social media. After this process, for example, a YouTube channel or an Instagram account can be opened and shares can be made from them and children can be approached developmentally." Another participant who emphasized that he developed 
his psychological skills during the COVID-19 period is: "I can say that I have gained this information, that is, the knowledge of how to motivate children, to be able to motivate them from a distance."

Figure 1.

Teachers Experiences in The Covid-19 Period

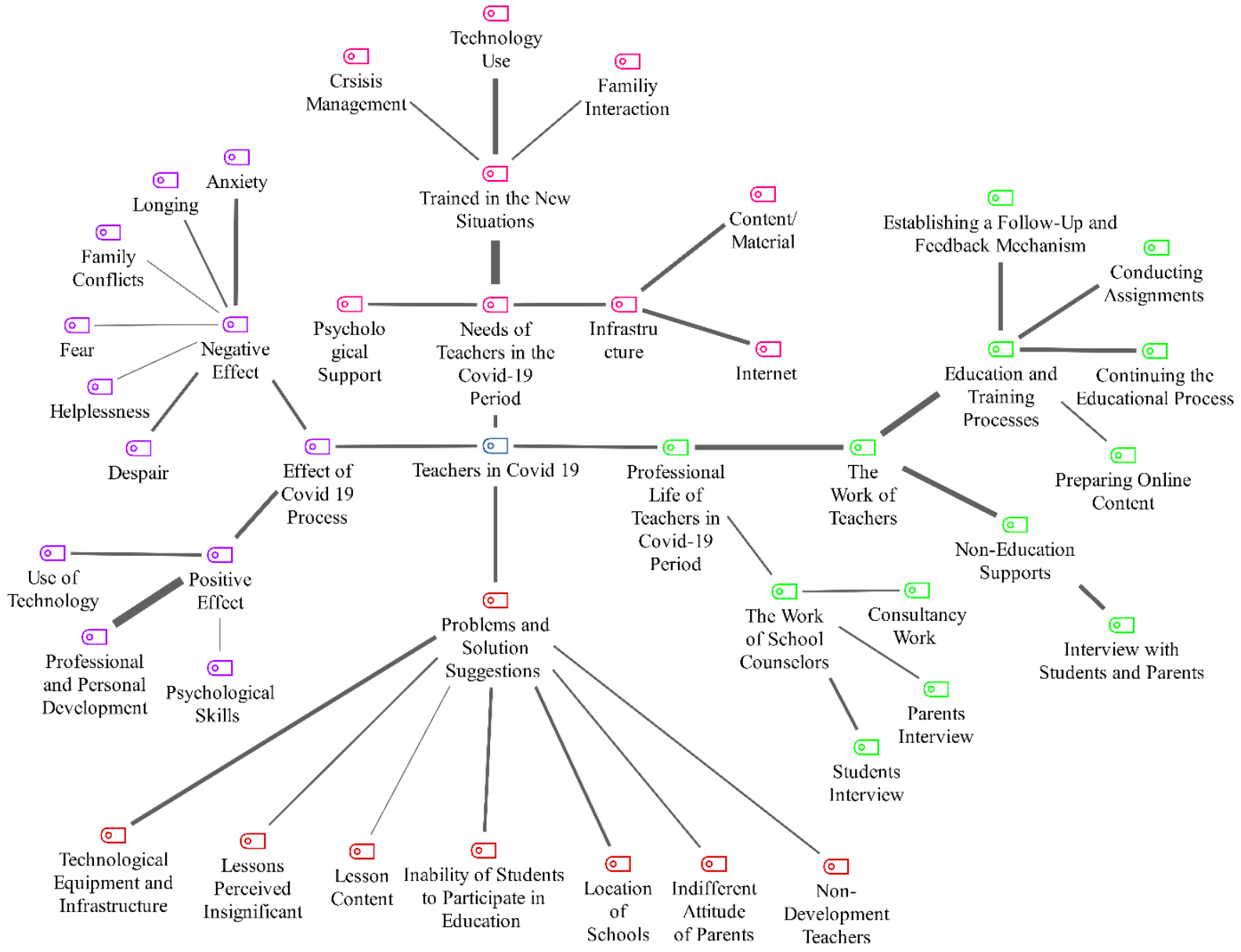

\section{Needs of Teachers in the COVID-19 Period}

The needs of teachers in the period COVID-19 have been brought up under the headings of psychological support, education and infrastructure. Emphasizing the need for psychological support for teachers, one participant stated that teachers need psychological support to effectively continue their duties and responsibilities in the COVID-19 process with the following statement: "Let them help us first, because the teacher will solve this crisis, but we need psychological help." Another participant emphasized the importance of psychological support for teachers to stay strong in this period and stated this as follows: "Therapy should start with teachers first; in this sense we may have had teachers who have lost loved ones. Maybe he is lost a relative, and he is worse off. First, they need psychological support. For example, teachers can also be given distance education about ways to cope with trauma, because if our power source is teachers, you should also support this power."

In addition to psychological support, teachers need to be trained in the new situations they face during the COVID-19 process. These trainings are organized under the headings of technology use, crisis management and family interaction. Teachers' needs for technology use appear to be linked to online classroom management, the use of technological elements, and content creation in online environments. For example, while a participant has been using the following statements: "I wish I were a little more expert on technological, electronic infrastructure. So, I know Web 2.0 tools vs, but I spend a lot of time on issues like what is technically done when sharing files vs on the computer. I would like to be more practical about these things." another participant has been stated his opinion as follows: "If this practice 
continues, our knowledge of what we teachers can do in online training is very, very limited. For example, I do not know how to reach a student, I do not know how to teach a subject to a child from a distance without touching, let them touch or feel."

Another title related to the training required by teachers is crisis management. Participants state that they need training in crisis coping and crisis management. "I'm trying to figure out how to turn a crisis into an opportunity or how to get rid of a crisis with minimal damage. I read various articles, I read books. I taught the kids breathing exercises. Because I am so got bored, and I don't know how to manage the crisis for them, to be honest."

Emphasizing the importance of developing family interaction, teachers feel the need for education to strengthen family interaction in this process: "And another important point is cooperation with the family, which is very, very important. This is already a very important title in our field from the very beginning, but it has become more important in this period."

The infrastructure is the final point for the needs of teachers. The needs for the internet and content/materials are particularly noteworthy in this point. Referring to the lack of content/material in the process, teachers expressed it as follows: "Since we're doing distance education, content needs to be enriched. Programs such as Morpa, Okulistik should be made available free of charge. In this process, such content can be formalized." Another participant expressed its views on the internet as follows: "So we need something like that... If everyone is going to be home, maybe 3 months 5 months 6 months in this process, we do not even know how long. So, in that process, our internet problem must be solved. I believe that if we can make a live connection on the internet, at least if the children see me, if I see them, we can somehow overcome it."

\section{Professional Life of Teachers in COVID-19 Period}

This title is studied under two main headings: the work of teachers and the work of school counselors. In this process, the teachers have worked under four main headings. Teachers are engaged in different professional experiences, such as preparing online content within the framework of educational processes, establishing a follow-up and feedback mechanism, conducting assignments and continuing the educational process. A teacher who tried to create new learning opportunities for his students in addition to existing resources expressed his opinion as follows: "I started making videos, especially in some classes. "To provide additional support to EBA TV or to support students with limited access. Some of our friends who have the opportunity are setting up, making videos, sending them to students". Another teacher performs the following practice in order for students to spend this period efficiently: "I want them to summarize after the lesson on EBA TV, I want them to ask themselves 5 questions from the summaries they have summarized. I create question pools from these 5 questions and devote 2 days a week to these question pools.". Another teacher who operates the feedback mechanism described the follow - up and feedback process as follows: "You will give children their homework every day, you will receive feedback, you will ask those who do not participate why they do not participate. You will meet with their families in any case. In addition, we also have a guidance counselor who has done a master's degree, we also contacted him face-to-face, our teacher was already in very good communication with parents. He met them face-to-face."

Besides the education and training processes, teachers have also carried out studies to improve the wellbeing of students and parents. As part of these studies, teachers have regularly conducted interviews to protect students and parents from the negative psychological effects of the epidemic process. "First, we divided our students on a weekly basis, identifying students for each teacher. In particular, there are already groups formed by classroom teachers, except for them, we, as branch teachers, call our students weekly, interview them." Teachers who have established the support mechanism for families have also created a separate social support mechanism for families in this period: "We also have a conversation for psychosocial support. We have started to keep in touch with them about things like what they are doing, how they are spending time with their families, and we will definitely do that on a weekly basis 
and create a report as well."

School counselors, who are experts in crisis management, stress and anxiety management in schools, presented parent interview, student interview, consultancy work in distance education process. Teachers receive support from psychological counselors on how to conduct the process: "I'm discussing with the school's counselor what I can do to cheer them up. He is giving me information about how I can handle this. He gives feedback on which books or who I can follow, or who I can be inspired by." In addition, school counselors prepare and deliver informative publications to students and parents and conduct parent interviews: "We have a counselor who has a master's degree. We also contacted him. In any case, our teacher was very well connected to the parents. He is met them directly. We have got about 215 parents, and he's in touch with all of them. The fact that he was a spiritual support to us made the process very easy for both us and the parents."

\section{Problems and Solution Suggestions Experienced by Teachers Regarding the Measures Taken in the COVID-19 Period}

Teachers have expressed criticism and suggestions on some of the major issues that they believe lead to reduced productivity and disruption of the compulsory distance learning process. Technological equipment and infrastructure are among the most significant issues for teachers. During this process, teachers criticized issues that EBA had been permanently frozen, did not have sufficient infrastructure, did not have the contents to cover the academic level of each student, most students were in the disadvantaged group and did not have access to EBA. A teacher expressed the problems experienced by teachers and students when using EBA as follows: "It's constantly kicking out of the system, it's freezing, you're trying to get back into the system. That is the feedback I get from your students. That is the result, I think it can be improved a little bit more, I'm not so desperate about it anyway." Another criticism is aimed at the content of the course. A participant stated that the content was not appropriate for student levels as follows: "It's not appropriate for the level of first class. Much abbreviated, is told very quickly, fast skipped over. Just reading writings. The children do not understand what's going on. It just ends, they don't understand anything, they just stare at it." Also, another participant expressed that the EBA does not have appropriate and adequate content for students with special needs and therefore cannot support their students at the level they want as follows: "I felt I needed more in the period. Yes, we need contact-based education, but we need online apps where students can remember what we teach, repeat it, and make it permanent. Yes, there are a few apps in the EBA but it is not enough because our children are so different, each one has different personal characteristic, so we need a lot more activities."

Participants stated that some courses were given weight during distance education and some were pushed into the background, creating the perception that these courses were unnecessary in students: "...Painting, music and physical education are presented only after children's lessons, after watching 20-minute lesson videos, during 10-minute playtimes, as a social activity and as a fun video. In this process, we faded back again, we were pushed into the background. Especially in this process, the lack of these lessons creates the perception that these lessons are insignificant in children. After this process, we can lose children who have talent, who are willing."

One of the participants addressed the issue of the inability of students to participate in education as follows, which is one of the problems encountered in the distance education process: "There are students who can't adapt to distance education. Now, for example, we teach via Zoom, but some people do not have the internet in their home. In my 40-person class, about 29-30 people attended classes. A quarter of the class is absent, 2 in 4 or 3 in 4 of them attending. " In addition, he drew attention to the problem of insufficient interaction between students as one of the most important reasons why distance education cannot replace formal education and the efficiency in the normal classroom environment cannot be achieved as follows: "Not as effective as formal education, of course, there is no great interaction in the between them. Children cannot establish a dialogue and communicate among themselves."

Teachers have stated that the location of schools can bring both some advantages and some 
disadvantages to the distance learning process. Some teachers expressed a large number of siblings as a disadvantage, an unrelated parent attitude, and internet/infrastructure problems caused by the location. Some teachers, on the other hand, expressed a conscious student and parent attitude as an advantage, teachers in the school were open to development, the school was located in a central location, and being a project school. A participant stated the disadvantaged situation experienced by the status of the school as follows: "It works for people living in big cities, it works for students studying in good schools. For disadvantaged students, the period was 10 times more difficult than the normal period. Think of the eastern provinces, think of the villages at the east. I cannot imagine how desperate they were and what they were doing. We also need psychological support, we are so desperate and so anxious and we feel so pushed back... we feel so helpless. I have illiterate parents. How do I get to that student, how do I sit down and prepare something for them, give them a homework? What should I do?"

Teachers have also criticized the indifferent attitude of parents, which they consider to be another cause of problems in the distance education process. A participant expressed his or her opinion as follows: "Here, of course, an irresponsible parent is also irresponsible. Two of them are permanently absent for both applications and distance education."

Teachers criticized not only parents, the system, or other teachers, but also themselves for not getting enough efficiency from the distance learning process. A teacher, which, like other teachers, stated that he was not open to development, used the following statements: "They are already having more trouble and giving up faster. It is more like learned desperation... When they try a little bit to see what can be done from distance, they immediately leave and give up. A little bit like the training we have had, let me speak for myself, we're not open to developing ourselves." Another teacher stated that the new generation is more advantageous than them in terms of the technology skills needed in this process, and that they are not sufficiently developed in this regard as follows: "We're probably Generation $Y$ in this age group right now. Generation $Y$ has a bit of a problem adapting to Generation $Z$ in this regard. They use technology better, so to speak. Maybe they are spending more time. It is not for educational purposes, it's more for fun, but our generation needs to use it not for fun, but for their field of education. Let me tell you, we're not as lucky as Generation Z."

\section{DISCUSSION}

The results of the research are structured around five main themes. These themes were defined as the effects of the COVID-19 process, the needs, the professional experience and the problems experienced and the solutions. The study found that the COVID-19 process had positive and negative effects on teachers. Negative effects include experiences such as anxiety, longing, conflict, fear, helplessness, and despair. Consistent with research results, Gammon (1999) identified that people get the feeling that in certain emotions during the process of social isolation, and these emotions are feeling limited, feeling imprisoned, depression, anxiety, and anger. Jonkman (2003) found that disasters and diseases cause emotional trauma, stress, depression, isolation, and behavioral changes in people. König et al. (2020) emphasize that the COVID-19 pandemic may cause many short-term or long-term psychological problems on people. In addition to these negative effects, it has also been found that teachers are positively affected by the process. In this process, teachers have focused on their professional and personal development, improving their use of technology and psychological skills. Features such as psychological flexibility, career adaptability and indomitability developed in this process contribute to the development of positive outcomes (Arslan, 2021; Arslan et al., 2020; Demir \& Ayaz, 2019; Fredrickson, 2003). Dempsey and Burke (2020) highlight the positive results of the ongoing process of school administrators closing schools as a result of their research. Dempsey and Burke (2020) and Sepulveda-Escobar and Morrison (2020) state that during the COVID-19 process, teachers accelerate their professional development, acquire new hobbies and continue their lives in a healthier way. MacIntyre et al. (2020) note that teachers who can use coping skills can be affected by this period in a healing way and achieve positive outcomes. 
Another theme that was developed within the scope of research outlines the needs of teachers. Among these needs, the need for psychological support, especially for teachers, will contribute to avoiding the negative effects of this process and to achieving positive outcomes. As MacIntyre et al., (2020) noted, teachers need to stimulate coping strategies. Collie, Bostwick and Martin (2020) emphasize that teachers need support for social support and adaptation. In addition, school staff who have higher self-efficacy, more positive attitudes towards distance education, and perceive higher levels of executive support experience less stress. (Košir et al., 2020).

For teachers to improve themselves through training was another demand that stand out among the findings. Wang et al. (2021) stated that teachers had a lack of preparation for the rapid transition to online education. Ewing and Cooper (2021) also found that teachers have difficulties in adapting to Covid-19. Darling-Hammond and Hyler (2020) emphasized that teachers should be prepared according to the needs that may arise during the COVID-19 process and its consequences. Teachers need to teach innovations with innovations and implement old teaching methods by enriching them with technology in order to prepare their students specifically for the world of the 21st century (Klopfer et al., 2009). Clark (2008) suggested that the lack of professional development activities for tool use are the most important factors affecting the use of technological tools by teachers. Garba et al. (2015) stated that the knowledge of techno-pedagogic content by teachers is low and that these skills should be developed as a priority in the development of learning environments in the 21 st century.

Another finding worth discussion, which stand out among the needs of teachers, was infrastructure. In this period, teachers need both content and materials for online education, as well as internet infrastructure for access to online services. Le Maistre and Paré (2008) noted that the lack of administrative support experienced by teachers, lack of ability to professionally manage crisis and personal problems, limited teaching resources, lack of expectations and needs, lack of professional development, and lack of crisis management are the main factors that lead to stress. Adigüzel and Yüksel (2012) and Ayaz and Karacan Özdemir (2021) stated that while teachers do not use technology alone in the classroom, by promoting it with their pedagogical skills, they can use it at a level which can be called good. König et al., (2020) have previously shown that teachers who actively use digital platforms do not find it difficult or even more efficient to use digital content in this process. In school, the frequent use of computer technology and digital platforms enhanced social communication and ensured the continuity of online courses. In a similar manner to this finding, Rasmitadila et al. (2020) and Kaden (2020) highlight teachers' infrastructure and internet problems.

During the COVID-19 period, teachers quickly adapted to the new process of education and training and tried to develop mechanisms for the efficient implementation of this process. The studies carried out during this period were conducted under the guidance of the Ministry of Education (Özer, 2020) and the studies were carried out on the initiative of teachers and psychological counsellors. Similar processes have taken place in other countries, such as Turkey (König et al., 2020). Kaden (2020) stated that along with COVID-19, teachers were urgently switching to online education. Kaden, who presents a portrait of a teacher in his research, highlights the transitions of teachers in the online education teaching process and the experiences they have gained in carrying out this process. Rasmitadila et al. (2020), on the other hand, emphasized how educational learning processes were progressing and what teachers are doing in these processes, similar to research findings. Also, Karacan Özdemir and Ayaz (2020) suggested that school counselling services in Turkey should adapt to technological changes in the world.

The final group of findings within the scope of the research included the problems of teachers and suggestions for solutions. The findings of Heberci et al. (2020) are similar to the results of the research. According to the researchers, technical problems and infrastructure problems arise in the distance education process, the number of courses and the way in which they are processed, the participation of students in the course, and the inability of students to follow. Kaden is another researcher who highlights the need for internet access and technical support among teachers' problems (2020). Kaden points out that solutions to these problems can be easily reached through collaboration between local government and Internet providers, as well as school management, teachers, parents and students. König et al. (2020) 
argue that the infrastructure of the online or distance education system should be strengthened as a solution to the problems experienced in this process and that all students should be able to access distance learning. He points out, however, that in-service training should be organized to improve the distance learning skills of teachers. He also points out that parents need to make an effort to compensate for their children's learning.

\section{CONCLUSION AND RECOMMENDATIONS}

The experience of teachers in the COVID-19 process has been discussed in this study. The results of the research show that teachers are negatively affected as well as positively affected by this process. In the case of teachers coming out of this process with positive results, it is important to note that they can use their characteristics, such as career adaptability, indomitability and psychological flexibility (Ayaz \& Demir, 2019; MacIntyre et al., 2020). Also, Incik and Özkan (2018) and Öztabay (2017) emphasize that teachers should be scientifically thinking, researching, creative, innovative, have high problem solving and communication skills, have field knowledge, open technological developments and have a good command of technology. Anxiety, fear, conflict, helplessness and desperation caused by teachers being negatively affected by this process lead to the need for psychological support. Psychological support for teachers will both work against the negative effects of the process and provide them with an opportunity to develop their protective factors.

Research results also show that teachers need to be supported both in terms of education and infrastructure. At this point, the in-service training to be given to teachers is coming to the fore. The work of the Ministry of Education (MoNE, 2020d) on this issue should be extended. It is recommended that these studies focus on crisis management, the use of technology, family interaction and content generation.

Research results also show that teachers and school counselors conduct similar face-to-face education studies in the COVID-19 process. However, the rapid transition to distance learning has led to complexities in this process and to the emergence of certain crisis situations. Following this process, it is recommended that teachers and managers train against possible crisis situations and develop action plans to prepare for similar crisis situations. With these and similar studies, the process of education and training can be continued with minimal damage in possible crisis situations (Kaden, 2020). Teachers and school psychological counselors also interviewed students and parents during this process. The interviews provided a source of social support to students and parents. In this way, they have a protective factor through the active use of social support resources in this process, which have negative consequences for mental health (Labrague \& De los Santos, 2020; Saltzman et al., 2020). These studies by teachers and psychological counselors have a protective effect on community mental health. It is recommended that these and similar studies be disseminated under the coordination of the Ministry of Education and under the supervision of school administrators.

In the context of the most recent findings within the scope of the research, the problems experienced in the distance education process have been highlighted and suggestions for solutions to these problems have been presented. Technological equipment and infrastructure, the inability of students to attend classes, the inability of teachers to improve, the apathy of parents, the resources of schools, all problems are basically obstacles to students' access to distance education during the COVID-19 period. The inability of students to access education, which is one of their basic rights for reasons beyond their control, will lead to an inability to achieve social justice (Hytten \& Bettez, 2011). In order to ensure that students have access to education, it is necessary to provide both internet and hardware support, as well as teacher and parent motivation. 


\section{REFERENCES}

Adigüzel, A. \& Yüksel, İ. (2012). Evaluation of teachers' instructional technologies integration skills: A qualitative need analysis for new pedagogical approaches. Necatibey Faculty of Education Electronic Journal of Science and Mathematics Education, 6(1), 265-286. http://www.nef.balikesir.edu.tr/ dergi/makaleler/yayinda/12/EFMED_FBE222.pdf

Allen, R., Jerrim, J., \& Sims, S. (2020, September). How did the early stages of the COVID-19 pandemic affect teacher wellbeing? Econ Papers. https://EconPapers.repec.org/RePEc:ucl:cepeow:20-15

Allen J., Rowan L., \& Singht, P. (2020). Teaching and teacher education in the time of COVID-19. Asia-Pacific Journal of Teacher Education. 223-236. https://doi.org/10.1080/1359866X.2020.1752051

Arslan, G. (2021). Loneliness, college belongingness, subjective vitality, and psychological adjustment during coronavirus pandemic: Development of the college belongingness questionnaire. Journal of Positive School Psychology, 5(1), 17-31. https://doi.org/10.47602/jpsp.v5i1.240

Arslan, G., Yıldırım, M., Tanhan, A., Buluş, M., \& Allen, K. A. (2020). Coronavirus stress, optimism-pessimism, psychological inflexibility, and psychological health: Psychometric properties of the Coronavirus Stress Measure. International Journal of Mental Health and Addiction, 1-17. https://doi.org/10.1007/s11469-02000337-6

Ananiadou, K. \& Rizza, C. (2010). ICT in initial teacher training: First findings and conclusions of an OECD study. Proceedings of EDULEARN10 Conference, (pp. 5621-5632). Barcelona, Spain. https://library.iated.org/view/ANANIADOU2010ICT

Ayaz, A. \& Karacan Özdemir, N. (2021). A case study of a Turkish vocational high school, and the challenges for teachers. Journal of Vocational Education \& $\quad$ Training. $1-20$. https://doi.org/10.1080/13636820.2021.1895873

Ayaz, A. \& Demir, Ö. O. (2019). The role of career adaptability in classifying teachers by educational level. Milli Ĕ̈itim Dergisi, 48(223), 147-158. https://dergipark.org.tr/en/download/article-file/790215

Barton, L. (2000). Crisis in organizations II. South-Western College Publishing.

Beijaard, D., Meijer, P. C. \& Verloop, N. (2004). Reconsidering research on teachers' professional identity. Teaching and Teacher Education, 20(2), 107-128. https://doi.org/10.1016/j.tate.2003.07.001

Bundy, J., Pfarrer, M. D., Short, C. E. \& Coombs, W. T. (2017). Crises and crisis management: Integration, interpretation, and research development. Journal of Management, 43(6) 1661-1692. https://doi.org/10.1177/0149206316680030

Dempsey, M. \& Burke, J. (2020). Covid-19 Practice in primary schools in Ireland report. Maynoot University. http://mural.maynoothuniversity.ie/13001/

Cai, X., Fu, J., Lu, Y., Tang, X., \& Zhong, S. (2020). Assessing Inequality in the School Closure Response to COVID-19. http://dx.doi.org/10.2139/ssrn.3632103

Carver, M. \& Shanks, R. (2021) New teachers' responses to COVID-19 in Scotland: Doing surprisingly well? Journal of Education for Teaching, 47(1), 118-120. https://doi.org/10.1080/02607476.2021.1874821

Carver, C. S., Scheier, M. F., \& Weintraub, J. K. (1989). Assessing coping strategies: A theoretically based approach. Journal of Personality and Social Psychology, 56, 267-283. https://psycnet.apa.org/doi/10.1037/0022-3514.56.2.267

Centers for Disease Control and Prevention Infection Control. (2020, June 3). Novel coronavirus, Wuhan, China. 2020. CDC. https://www.cdc.gov/coronavirus/2019-ncov/hcp/infection-control.html

Clark, J. (2008). PowerPoint and pedagogy: Maintaining student interest in university lectures. College Teaching, 56(1), 39-44. https://doi.org/10.3200/CTCH.56.1.39-46

Creswell, J. W. (2012). Educational research: Planning, conducting, and evaluating quantitative (4 ${ }^{\text {th }}$ ed.). Pearson.

Collie, R., Bostwick, K., \& Martin, A. J. (2020). Perceived autonomy support, relatedness with students, and workplace outcomes: An investigation of differences by teacher gender. Educational Psychology, 40, 253272. https://doi.org/10.1080/01443410.2019.1663791

Conley, S. C. \& Odden, A. (1995). Linking teaching compensation to teacher career development. Educational Evaluation and Policy Analysis, 17, 219-237. https://doi.org/10.3102\%2F01623737017002219

Council of Higher Education (CoHE), (2018). Teacher training undergraduate programs. YOK. www.yok.gov.tr/Documents/Kurumsal/egitim_ogretim_dairesi/Yeni-Ogretmen-Yetistirme-LisansProgramlari/AA_Sunus_\%20Onsoz_Uygulama_Yonergesi.pdf

Darling-Hammond, L. \& Hyler, M.E. (2020). Preparing educators for the time of covid and beyond. European Journal of Teacher Education, 43,457-465. https://doi.org/10.1080/02619768.2020.1816961

Demir, Ö. O. \& Ayaz, A. (2019). The role of career adaptability in work status of the graduates of psychological counseling and guidance department. The Western Anatolia Journal of Educational Sciences (WAJES) 10(1), 28-36. https://dergipark.org.tr/en/pub/baebd/issue/46306/514239 
Demirli-Yıldız, Sevil-Gülen, Ö. \& Erdur Baker, Ö. (2016). Crisis, crisis response and crisis counseling. Ö. ErdurBaker, T. Doğan (Eds.) Crisis counseling (pp. 3-26). Pegem.

Echterling, L. G., Presbury, J. H. \& McKee, J. E. (2005). Crisis intervention: Promoting resilience and solution in troubled times. Merrill/Prentice Hall.

Ergün, M., \& Arık, BM (2020). Education monitoring report 2020: Students and access to education. Education Reform Initiative. Eğitim Reform Girişimi. https://www.egitimreformugirisimi.org/egitim-izleme-raporu2020-ogrenciler-ve-egitime-erisim/

Enochsson, A. \& C. Rizza (2009). ICT in Initial Teacher Training: Research Review, OECD Education Working Papers, No. 38, OECD Publishing. https://www.oecd-ilibrary.org/education/ict-in-initial-teacher-trainingresearch-review_220502872611

Europe Commission, (2013). Supporting teacher competence development: For better earning outcomes. EC. https://ec.europa.eu/assets/eac/education/policy/school/doc/teachercomp_en.pdf

European Centre for Disease Prevention and Control (ECDC). (2020). COVID-19 situation update worldwide, as of week 52 2020. ECDC. https://www.ecdc.europa.eu/en/geographical-distribution-2019-ncov-cases

Ewing, L. A., \& Cooper, H. B. (2021). Technology-enabled remote learning during COVID-19: perspectives of Australian teachers, students and parents. Technology, Pedagogy and Education, 1-17. https://doi.org/10.1080/1475939X.2020.1868562

Fagell, P. L. (2020). Career Confidential: Distance learning frustrations. Phi Delta Kappan, 102(3), 66-67. https://doi.org/10.1177/0031721720970708

Fisher, D. \& Heymann, D. (2020). Q\&a: The novel coronavirus outbreak causing COVID-19. BMC Medicine, 18(57). https://doi.org/10.1186/s12916-020-01533-w

Fredrickson, B. L. (2003). The value of positive emotions: The emerging science of positive psychology is coming to understand why it's good to feel good. American Scientist, 91(4), 330-335. https://www.americanscientist.org/sites/americanscientist.org/files/20058214332_306.pdf

Gammon J .(1999). The psychological consequences of source isolation: A review of the literature. Journal of Clinical Nursing, 8(1), 13-21. https://doi.org/10.1046/j.1365-2702.1999.00201.x

Gan, M. A., Kousky, V.E., \& Ropelewski, C.F. (2004). The South America monsoon circulation and its relationship to rainfall over west-central Brazil. Journal Climate, 17, 47-66. https://doi.org/10.1175/15200442(2004)017\%3C0047:TSAMCA\%3E2.0.CO;2

Garba, S. A., Byabazaire, Y. \& Busthami, A. H. (2015). Toward the use of $21^{\text {st }}$ century teaching-learning approaches: The trend of development in Malaysian schools within the context of Asia Pacific. International Journal of Emerging Technologies in Learning, 10(4), 72-29. http://dx.doi.org/10.3991/ijet.v10i4.4717

Giovannella, C., Passarelli, M., \& Persico, D. (2020), Measuring the effect of the Covid-19 pandemic on the Italian Learning Ecosystems at the steady state: a school teachers' perspective. https://www.researchgate.net/publication/343127257_Measuring_the_effect_of_the_Covid19_pandemic_ on_the_Italian_Learning_Ecosystems_at_the_steady_state_a_school_teachers\%27_perspective

Güngör, A., Karaman, M. A., Sarı, H. İ., \& Çolak, T. S. (2020). Investigating the factors related to coronavirus disease 2019 (COVID-19) on undergraduate students' interests in coursework. International Journal of Psychology and Educational Sciences, 7(3), 1-13. http://dx.doi.org/10.17220/ijpes.2020.03.001

Haney, J. J., \& Lumpe, A. T. (1995). A teacher professional development framework guided by reform policies, teachers' needs, and research. Journal of Science Teacher Education, 6(4), 187-196. https://doi.org/10.1007/BF02614642

Heberci, M. T., Bertiz, Y., \& Alan, S. (2020). Investigation of views of students and teachers on distance education practices during the coronavirus (COVID-19) pandemic. International Journal of Technology in Education and Science, 4(4), 267-282. https://doi.org/10.46328/ijtes.v4i4.113

Hopkins, D., \& Stern, D. (1996). Quality teachers, quality schools: International perspectives and policy implications. Teaching and Teacher Education, 12(5), 501-517. https://doi.org/10.1016/0742$051 \mathrm{X}(95) 00055-\mathrm{O}$

Huberman, M. (1989). The professional life cycle of teachers. Teachers College Record, 91, 31-57. https://psycnet.apa.org/record/1990-05987-001

Huda, M., Anshari, M., Almunawar, M.N., Shahrill, M., Tan, A., Jaidin, J.H., \& Masri, M. (2016). Innovative teaching in higher education: The big data approach. The Turkish Online Journal of Educational Technology, 15, 1210-1216. https://online-journals.org/index.php/i-jet/article/view/6434

Hytten, K., \& Bettez, S. C. (2011). Understanding education for social justice. The Journal of Educational Foundations, 25, 7-24. https://eric.ed.gov/?id=EJ925898

Incik, E. Y., \& Özkan, C. (2018). Teacher training system: According to the views of academicians and teacher candidates. Turkish Journal of Education, 7(1), 18-33. https://doi.org/10.19128/turje.334935 
Jonkman, S. N., Van Gelder, P. H. A. J. M, and Vrijling, J. K., (2003). An overview of quantitative risk measures for loss of life and economic damage. Journal of Hazardous. Materials, 99(1), 1-30. https://doi.org/10.1016/S0304-3894(02)00283-2

Kaden, U. (2020). COVID-19 school closure-related changes to the professional life of a K-12 teacher. Education Sciences, 10(6), 165. http://dx.doi.org/10.3390/educsci10060165

Kaendler, C., Wiedmann, M., Rummel, N., \& Spada, H. (2015). Teacher competencies for the implementation of collaborative learning in the classroom: A framework and research review. Education Psychology Review, 27, 505-536. http://dx.doi.org/10.1007/s10648-014-9288-9

Karaman, M. A., Eşici, H., Tomar, İ. H., \& Aliyev, R. (2021). COVID-19: Are school counseling services ready? Students' psychological symptoms, school counselors' views, and solutions. Frontiers in Psychology, 12, 1-14. https://doi.org/10.3389/fpsyg.2021.647740

Karacan Özdemir, N \& Ayaz, A. (2020). Construction of career development services according to industry 4.0: needs, priorities and requirements. Journal of Higher Education and Science 10(1), 96-102. http://higheredu-sci.beun.edu.tr/text.php3?doi=10.5961/jhes.2020.371

Khusid, J. A., Weinstein, C. S., Becerra, A. Z., Kashani, M., Robins, D. J., Fink, L. E., ... \& Weiss, J. P. (2020). Well-Being and Education of Urology Residents During the COVID-19 Pandemic: Results of an American National Survey. The International Journal of Clinical Practice, 1-8. https://doi.org/10.1111/ijcp.13559

Klopfer, E., Osterweil, S., Groff, J., Haas, J. (2009). Using the technology of today, in the classroom today: The instructional power of digital gaming and social networking and how teachers can leverage it. The Education Arcade Massachusetts Institute of Technology. http://education.mit.edu/wpcontent/uploads/2018/10/GamesSimsSocNets_EdArcade.pdf

Košir, K., Dugonik, Š., Huskić, A., Gračner, J., Kokol, Z., \& Krajnc, Ž. (2020). Predictors of perceived teachers' and school counsellors' work stress in the transition period of online education in schools during the COVID-19 pandemic. Educational Studies, 1-5. https://doi.org/10.1080/03055698.2020.1833840

König, J., Jäger-Biela, D. J. \& Glutsch, N. (2020). Adapting to online teaching during COVID-19 school closure: Teacher education and teacher competence effects among early career teachers in Germany. European Journal of Teacher Education, 43(4), 608-622. https://doi.org/10.1080/02619768.2020.1809650

Labrague, L. J. \& De los Santos, J. A. A. (2020). COVID-19 anxiety among front-line nurses: Predictive role of organisational support, personal resilience and social support. Journal of Nursing Management, 28(7), 1653-1661. https://doi.org/10.1111/jonm.13121

Lau, J., Yang, B. \& Dasgupta, R. (2020, March 12). Will the coronavirus make online education go viral? Times Higher Education. https://www.timeshighereducation.com/features/will-coronavirus-make-onlineeducation-go-viral

Le Maistre, C. \& Paré, A. (2010). Whatever it takes: How beginning teachers learn to survive. Teaching and Teacher Education, 26, 559-564. https://doi.org/10.1016/j.tate.2009.06.016

Lee, J. (2020). Mental health effects of school closures during COVID-19. The Lancet Child \& Adolescent Health, 4, 421. https://doi.org/10.1016/S2352-4642(20)30109-7

Lefstein, A., \& Perath, H. (2014). Empowering teacher voices in an education policy discussion: Paradoxes of representation. Teaching and Teacher Education, 38, 33-43. http://dx.doi.org/10.1016/j.tate.2013.11.001

Lent, R. W., Brown, S. D., \& Hackett, G. (2000). Contextual supports and barriers to career choice: A social cognitive analysis. Journal of Counseling Psychology, 47(1), 36-49. https://doi.apa.org/doi/10.1037/00220167.47.1.36

Lestiyanawatir. (2020, May 31). The strategies and problems faced by Indonesian teachers in conducting elearning during COVID-19 outbreak. CLLIENT (Culture, Literature, Linguistics, English Teaching), 2(1), 71-82. https://ojs.unsiq.ac.id/index.php/cllient/article/view/1271

Livingstone, S. (2012). Critical reflections on the benefits of ICT in education. Oxford Review of Education, 38(1), 9-24. https://doi.org/10.1080 / 03054985.2011.577938

MacIntyre, P.D., Gregersen, T. \& Mercer, S. (2020). 'Language teachers' coping strategies during the Covid-19 conversion to online teaching: Correlations with stress, wellbeing and negative emotions. System, 94, 1-13. https://doi.org/10.1016/j.system.2020.102352

Main, M., Hesse, E. \& Hesse, S. (2011). Attachment theory and research: Overview with suggested applications. Family Court Review, 49(3), 426- 463. https://doi.org/10.1111/j.1744-1617.2011.01383.x

Maya, M. L. (2014). Venezuela: The political crisis of post-chavismo. Social Justice, 40(4), 68-87. https://www.jstor.org/stable/24361611

Miles, M, B., \& Huberman, A. M. (1994). Qualitative data analysis: An expanded Sourcebook. (2 ${ }^{\text {nd }}$ ed). Sage.

Ministry of Health of the Republic of Turkey (2020, December 7). COVID-19 (Sars-Cov-2 Infection) general information, epidemiology and diagnosis. Saglik. https://covid19.saglik.gov.tr/TR-66337/genel-bilgilerepidemiyoloji-ve-tani.html

Noonan, J. (2018). An affinity for learning: Teacher identity and powerful professional development. Journal of Teacher Education, 70(5), 1-12. https://doi.org/10.1177/0022487118788838 
Olsen, B. \& Anderson, L. (2007). Courses of action a qualitative investigation into urban teacher retention and career development. Urban Education, 42(1), 5-29. https://doi.org/10.1177\%2F0042085906293923

Özer, M. (2020). Educational policy actions by the ministry of national education in the times of COVID-19 pandemic in Turkey. Kastamonu Education Journal, 28(3), 1124-1129. https://doi.org/10.24106/kefdergi.722280

Öztabay, C., (2017). Profiling research-capable English teachers throughout Turkey's national teacher education reform history. Turkish Journal of Education, 6(3), 96- 112. https://doi.org/10.19128/turje.296362

Purwanto, A., Asbari, M., Fahlevi, M., Mufid, A., Agistiawati, E., Cahyono, Y. \& Suryani, P. (2020). Impact of work from home (wfh) on Indonesian teachers performance during the Covid-19 pandemic: An exploratory study. International Journal of Advanced Science and Technology, 29(5), 6235-6244. https://d1wqtxts1xzle7.cloudfront.net/63324598/15627-Article_Text-23260-1-10-2020051520200515100344-11oup3s.pdf

Rasmitadila, R., Rusi, R., Aliyyah, R., Rachmadtullah, A., Samsudin, E. S., Muhammad N., Anna, R., Suryanti, T. (2020). The perceptions of primary school teachers of online learning during the Covid-19 pandemic period: A case study in Indonesia. Journal of Ethics and Cultural Studies, 7(2), 90-109. http://dx.doi.org/10.29333/ejecs/388

Republic of Turkey Ministry of National Education (MoNE). (2006). Evaluation of in-service training activities of the Ministry of National Education. MEB. http://www.meb.gov.tr/earged/earged/Hie_degerlendirme.pdf

Republic of Turkey Ministry of National Education (MoNE). (2017). Teacher profession general competencies. MEB.

http://oygm.meb.gov.tr/meb_iys_dosyalar/2017_12/11115355_YYRETMENLYK_MESLEYY_GENEL_ YETERLYKLERY.pdf

Republic of Turkey Ministry of National Education (MoNE). (2020a, March 12). Minister Selçuk announced the measures taken in the field of education against coronavirus. MEB. https://www.meb.gov.tr/bakan-selcukkoronaviruse-karsi-egitim-alaninda-alinan-tedbirleri-acikladi/haber/20497/tr

Republic of Turkey Ministry of National Education (MoNE). (2020b). Monitoring and evaluation report 2020. Distance education during the global outbreak. MEB. http://covid19.meb.gov.tr/assets/files/02-raporyayin-bilgilendirme/04-raporlar/01.pdf

Republic of Turkey Ministry of National Education (MoNE). (2020c). Teachers' in-service training plan. MEB. https://oygm.meb.gov.tr/meb_iys_dosyalar/2020_02/13170757_2019_Ogretmenlerin_Hizmetici_Egitim_ Plani.pdf

Republic of Turkey Ministry of National Education (MoNE). (2020d, October 13). We are making the biggest teacher education study in the history of Turkish education. MEB. https://oygm.meb.gov.tr/www/turkegitim-tarihinin-en-buyuk-ogretmen-egitimi-calismasini-yapiyoruz/icerik/836

Saltzman, L. Y., Hansel, T. C. \& Bordnick, P. S. (2020). Loneliness, isolation, and social support factors in postCOVID-19 mental health. Psychological Trauma: Theory, Research, Practice, and Policy, 12(1), 55-57. https://doi.org/10.1037/tra0000703

Sarı, D., \& Khorshid, L. (2008). The psychological consequences of source isolation to communicable diseases. Journal of Ege University Nursing Faculty, https://dergipark.org.tr/tr/pub/egehemsire/issue/49596/635551

Sepulveda-Escobar, P., \& Morrison, A. (2020). Online teaching placement during the COVID-19 pandemic in Chile: Challenges and opportunities. European Journal of Teacher Education, 43(4), 587-607. https://doi.org/10.1080/02619768.2020.1820981

Supriyanto, A., Hartini, S., Irdasari, W. N., Miftahul, A., Oktapiana, S., \& Mumpuni, S. D. (2020). Teacher professional quality: Counselling services with technology in Pandemic Covid-19. Counsellia: Jurnal Bimbingan dan Konseling, 10(2), 176-189. http://e-journal.unipma.ac.id/index.php/JBK/article/view/7768

Şen, F. \& Bat1, F. (2020). COVID-19 pandemic crisis and possible effects on management and political economy. Journal of Management, Economic and Marketing Research, 4(2), 71-84. https://doi.org/10.29226/TR1001.2020.186

Tein, J.Y., Sandler, I. N., \& Zautra, A. J. (2000). Stressful life events, psychological distress, coping, and parenting of divorced mothers: A longitudinal study. Journal of Family Psychology, 14(1), 27-41. https://doi.org/10.1037/0893-3200.14.1.27

Truzoli, R., Pirola, V., \& Conte, S. (2021). The impact of risk and protective factors on online teaching experience in high school Italian teachers during the COVID-19 pandemic. Journal of Computer Assisted Learning, 113. https://doi.org/10.1111/jcal.12533

United Nations Educational, Scientific and Cultural Organization (UNESCO). (2020). COVID-19 educational disruption and response. UNESCO. https://en.unesco.org/news/covid-19-educational-disruption-andresponse

United Nations (UN). (2020). Everyone included: Social impact of COVID-19. United Nations https://www.un.org/development/desa/dspd/everyone-included-covid-19.html 
Varvel, V. E. (2007). Master online teacher competencies. Online Journal of Distance Learning Administration, 10(1), 1-41. https://www2.westga.edu/ distance/ojdla/spring101/varvel101.htm

Wang, Z., Pang, H., Zhou, J., Ma, Y. \& Wang, Z. (2021). "What if horizontal ellipsis it never ends?": Examining challenges in primary teachers' experience during the wholly online teaching. Journal of Educational Research, 114, 89-103. https://doi.org/10.1080/00220671.2021.1884823

Wayman, J. C. \& Jimerson, J. B. (2014). Teacher needs for data-related professional learning. Studies in Educational Evaluation, 42, 25-34. https://doi.org/10.1016/j.stueduc.2013.11.001

World Economic Forum (2020). Global competitiveness report special edition 2020: How countries are performing on the road to recovery. Weforum. http://www3.weforum.org/docs/WEF_TheGlobalCompetitivenessReport2020.pdf

World Health Organization (WHO). (2020a, October 12). Coronavirus disease (COVID-19). World Health Organization. https://www.who.int/emergencies/diseases/novel-coronavirus-2019/question-and-answershub/q-a-detail/coronavirus-disease-covid-19

World Health Organization (WHO). (2020b). Strategic and technical advisory group for infectious hazards $(S T A G-I H)$. World Health Organization. https://www.who.int/emergencies/diseases/strategic-andtechnical-advisory-group-for-infectious-hazards/en/

Yamamoto, G.T. \& Altun, D. (2020). The coronavirus and the rising of online education. Journal of University Research, 3(1), 25-34. https://doi.org/10.32329/uad.711110

Yildirim, A., \& Şimşek, H. (2016). Qualitative research methods. Seçkin 


\section{TÜRKÇE GENIŞLETILMIŞ ÖZET}

Salgının etkisinin artması ile alınan önlemler ülkelerin sağlık sistemleri ile birlikte, ekonomik, sosyal ve eğitim sistemlerini de derinden etkilemiștir (CDC, 2020; Șen ve Batı; 2020). Türkiye'de alınan önlemler kapsamında ise kısa sürede uzaktan eğitim süreci başlatılmıştır (MoNE, 2020a). Alınan tedbirler ile bir yandan hayatta kalmaya, salgına bulaşmamaya ve bulaştırmamaya çalışan öğretmenler, diğer taraftan uzaktan eğitim ile öğrencilerinin eğitim-öğretim, gelişim ve psiko-sosyal ihtiyaçlarını gidermeye çalışmak durumunda kalmıştır. Bu dönemde ne tür psikolojik zorluklar yaşadıkları, mesleklerini nasıl sürdürdükleri ve kariyer gelişimleri için nelere ihtiyaç duydukları önemli hale gelmiștir. Bu çalışma ile Türkiye'de COVID 19 sürecinin öğretmenlerin üzerinde oluşturduğu psikolojik etkilerin, mesleki çalışmalarında gerçekleştirdiği uygulamaların ve kariyer ihtiyaçlarının belirlenmesi amaçlanmıştır.

Araştırma kapsamında öğretmenlerin COVID-19 sürecindeki mesleki yaşantılarının derinlemesine incelenmesi amaçlanmıştır. $\mathrm{Bu}$ kapsamda nitel araştırma yöntemlerinden fenomenoloji deseni kullanılmıştır (Yıldırım ve Şimşek, 2016). Çalışma grubu maksimum çeşitleme örnekleme yöntemi kullanılarak oluşturulmuştur. Bu kapsamda katılımcıların branş, yaş ve şehir değişkenleri arasından çeşitlendirilmesi hedeflenmiştir. Bu kapsamda 14 katılımcıyla bireysel görüşme yapılırken, 76 katılımcıdan çevrimiçi form aracılıyla veri toplanmıştır. Veri toplama sürecinde kullanılan bireysel görüşmeler araştırmacılar tarafından geliştirilen form aracılığıyla toplanmıştır. Bireysel görüşme formu ile COVID-19 sürecinin öğretmenler üzerindeki psikolojik etkilerinin, eğitim öğretim süreçlerine yansımalarının ve ortaya çıkardığı kariyer ihtiyaçlarının derinlemesine incelenmesi amaçlanmıştır. Görüşme formu altı sorudan oluşmaktadır. Bu sorular öğretmenlerin COVID-19 sürecinde kariyerlerine ilişkin yaşadıkları problemleri, ihtiyaçlarını, mesleki yaşantılarını ve sürecin etkilerini keşfetmeye yöneliktir. Görüşme formunun geliştirilmesi sürecinde Rehberlik ve Psikolojik Danışmanlık alanında uzman iki, Nitel araştırma yöntemleri konusunda uzman bir akademisyenden uzman görüşü alınmıştır. Uzman görüşleriyle birlikte görüşme formunun son hali elde edilmiş ve veri toplama süreci başlamıştır. Araştırma kapsamında kullanılan ikinci veri toplama aracı olan çevrimiçi anket formu ise bireysel görüşme formuyla aynı doğrultuda hazırlanmıştır. Açık uçlu sorulardan oluşan form ile katılımcıların deneyimlerine ilişkin daha detaylı bilgilerin elde edilmesi amaçlanmıştır. Araştırmanın inandırıcılık ve tutarlılı̆̆ını arttırmak amacıyla Creswell (2012), Yıldırım ve Şimşek (2016) ve Miles ve Huberman'ın (1994) önerileri doğrultusunda birtakım önlemler alınmıştır. Bu kapsamda araştırma ekibi düzenli aralıklarla bir araya gelmiş ve veri analizi aşamasında gerçekleştirilen ortak kodlamalar bu toplantılarda gerçekleştirilmiştir. Bununla birlikte katılımcı teyitleri alınmıştır. Ek olarak araştırmanın hem yöntem bölümü hem de bulgular bölümü zengin ve detaylı betimleme yöntemini temel alınarak hazırlanmıştır. Yöntem bölümünde araştırma sürecine ilişkin bilgiler detaylandırılarak aktarılırken, bulgular kısmı katılımcıların doğrudan ifadeleriyle birlikte raporlanmıştır. Son olarak araştırma kapsamında hem görüşme hem de açık uçlu sorulardan oluşan online anket formu aracılığıyla veri toplanmış ve veri çeşitlemesi sağlanmıştır. Görüşmeler ve çevrimiçi formlar aracılığıyla toplanan veriler araştırmacılar tarafından deşifre edilmiş ve MAXQDA 20 programı ile analiz edilmiştir.

Yapılan içerik analizi sonucunda dört ana tema belirlenmiştir. Bu temalar sırasıyla COVID-19 sürecinin öğretmenler üzerindeki etkileri, öğretmenlerin ihtiyaçları, öğretmenlerin mesleki yaşantıları ve alınan tedbirlere ilişkin öğretmenlerin yaşadığı problemler ve çözüm önerileridir.

COVID-19 sürecinin öğretmenler üzerindeki etkileri negatif ve pozitif etkiler olmak üzere iki temaya ayrılmıştır. Öğretmenlerin sürece ilişkin ifade ettikleri negatif etkiler arasında kaygı, özlem, aile içi çatışmalar, korku, çaresizlik ve umutsuzluk yer almaktadır. Katılımcılar arasında, negatif etkiler arasında en yoğun görünen kaygıdır. COVID-19 sürecinde öğretmenlerin süreç ile ilgili ifade ettikleri pozitif etkiler arasında; mesleki ve kişisel gelişim, teknoloji kullanımı ve psikolojik beceriler yer almaktadır. Katılımcılar arasında mesleki ve kişisel gelişim en çok tekrarlanan etki olarak göze çarpmaktadır. 
COVID-19 sürecinde öğretmenlerin ihtiyaçları psikolojik destek, eğitim ve altyapı başlıkları altında toplanmıştır. Psikolojik destekle birlikte öğretmenler bu süreçte psikolojik destek ihtiyaçlarını vurgulamış ve profesyonel destek almak istediklerini belirtmişlerdir. Ayrıca öğretmenler COVID-19 sürecinde karşılaştıkları yeni durumlara yönelik eğitim alma ihtiyacı içindedirler. Bu eğitimler teknoloji kullanımı, kriz yönetimi ve aile ile etkileşim başlıkları altında toplanmaktadır. Öğretmenlerin teknoloji kullanımına yönelik ihtiyaçlarının çevrimiçi sınıf yönetimi, teknolojik ögelerin kullanımı ve çevrimiçi ortamlarda içerik üretme ile ilişkili olduğu görülmektedir. Öğretmenlerin ihtiyaç duyduğu eğitimlere ilişkin bir diğer başlık ise kriz yönetimidir. Katılımcılar özellikle COVID-19 ile birlikte ortaya çıan yeni kriz durumları ile başa çıkma ve yönetme konusunda eğitime ihtiyaç duyduklarını belirtmektedirler. Ayrıca aile ile etkileşimi geliştirmenin önemini vurgulayan öğretmenler bu süreçte aile etkileşimini güçlendirmeye yönelik eğitim almak istemektedirler. Öğretmenlerin ihtiyaçlarına yönelik son alan ise alt yapıdır. Bu alanda özellikle internet ve içerik/materyal geliştirmeye yönelik ihtiyaçlar dikkat çekicidir.

COVID-19 sürecinde öğretmenlerin mesleki yaşantıları öğretmenlerin çalışmaları ve okul psikolojik danışmanlarının çalışmaları olarak iki ana başlık altında incelenmiştir. Öğretmenler bu süreçte çalışmaları dört ana başlık altında yürümüşlerdir. Öğretmenler eğitim-öğretim süreçleri kapsamında çevrimiçi içerik hazırlama, takip ve geribildirim mekanizması kurma, ödevlendirmeler yapma ve eğitim öğretim sürecini devam ettirme gibi farklı mesleki yaşantılar içindedirler. Öğretmenler eğitim öğretim süreçleri dışında da öğrenci ve velilerin iyi oluş düzeylerini geliştirmeye yönelik çalışmalar da gerçekleştirmişlerdir. Bu çalışmalar kapsamında öğretmenler, öğrenci ve velileri salgın sürecinin olumsuz psikolojik etkilerinden korumak amacıyla düzenli olarak görüşmeler gerçekleştirmişlerdir. Okullarda kriz yönetimi, stres ve kayg1 yönetimi gibi konularda uzman olan okul psikolojik danışmanları uzaktan eğitim sürecinde veli görüşmesi, öğrenci görüşmesi, müşavirlik çalışmaları sunmuşlardır. Ayrıca öğretmenler psikolojik danışmanlardan süreci nasıl yürütebileceklerine ilişkin destek almaktadır.

COVID-19 sürecinde alınan tedbirlere ilişkin öğretmenlerin yaşadığı problemler ve çözüm önerileri arasında en büyük yoğunluk teknolojik donanım ve altyapı üzerinedir. Bunula birlikte öğretmenler bazı ders içeriklerinin öğrenci düzeyine uygun hazırlanmadığını da vurgulamaktadırlar. Katılımcılar uzaktan eğitim sürecinde bazı derslere ağırlık verildiğini bazılarının ise ikinci plana atıldığını, bunun öğrencilerde bu derslerin gereksiz olduğu algısını yarattığını söylemişlerdir. Öğrencilerin eğitim öğretim sürecine katılmaması ise ayrı bir problem alanıdır. Ayrıca öğretmenler okullarının konumlarının uzaktan eğitim sürecine hem bazı avantajlar hem de bazı dezavantajlar getirebildiğini ifade etmişlerdir. Bazı öğretmenler dezavantaj olarak kardeş sayısının fazla olmasını, ilgisiz veli tutumunu ve konumdan ötürü ortaya çıkan internet/altyapı sorunlarını dile getirirken; bazı öğretmenler avantaj olarak bilinçli öğrenci ve veli tutumunu, okuldaki öğretmenlerin gelişime açık olmasını, okulun merkezi bir konumda bulunmasını ve proje okul olmasını dile getirmişlerdir. Öğretmenler uzaktan eğitim sürecinde yaşanan sorunların temelindeki bir diğer neden olarak düşündükleri velilerin ilgisiz tutumunu da eleştirmişlerdir. Öğretmenler uzaktan eğitim sürecinden yeterli verim alınamaması konusunda sadece velileri, sistemi veya diğer öğretmenleri değil kendilerini de eleştirmişlerdir. Öğretmenlerin gelişime açık olmaları ve kendilerini yenilemeleri vurgulanmıştır.

Araştırmadan elde edilen sonuçlar öğretmenlerin bu süreçten olumsuz yönde etkilendiği gibi olumlu yönde de etkilendiklerini göstermektedir. Öğretmenlerin bu süreçten olumlu çıktılarla ayrılmalarında ise yılmazlık ve psikolojik esneklik gibi özelliklerini kullanabiliyor olmaları ön plana çıkmaktadır (MacIntyre vd., 2020). Araştırma sonuçları aynı zamanda öğretmenlerin hem eğitsel hem de alt yapı açısından desteklenmeleri gerektiğini göstermektedir. Ayrıca öğretmenlerin ve okul psikolojik danışmanlarının COVID-19 sürecinde yüz yüze eğitimde gerçekleştirdiği çalışmalara benzer çalışmalar yaptıklarını göstermektedir. Ancak uzaktan eğitim sürecine hızlı geçiş bu süreçte karmaşıklıkların oluşmasına ve bazı kriz durumlarının ortaya çıkmasına neden olmuştur. Bu süreç sonrasında da benzer kriz durumlarına hazırlıklı olunması için öğretmenlerin ve yöneticilerin olası kriz durumlarına karşı eğitilmeleri ve eylem planları geliştirmeleri önerilmektedir. Son olarak COVID-19 sürecinde yaşanan sorunlar arasında teknolojik donanım ve alt yapı, öğrencilerin derslere katılamaması, öğretmenlerin 
gelişime kapalı olması, velilerin ilgisizliği, okulların konumundan kaynakları sorunlar öğrencilerin COVID-19 sürecinde uzaktan eğitime erişimlerinin önündeki engellerdir. Öğrencilerin kendi kontrolleri dahilinde olmayan sebeplerle temel hakları arasında yer alan eğitime erişememeleri sosyal adaletin sağlanamamasına neden olacaktır (Hytten ve Bettez, 2011). 